Hispania Sacra, LX

122, julio-diciembre 2008, 531-555, ISSN: 0018-215-X

\title{
«UNA COLUMNA FORTÍSIMA DEL ALTAR Y DEL TRONO»: PEDRO GUTIÉRREZ DE COS, OBISPO DE HUAMANGA Y DE PUERTO RICO (1750-1833)
}

\author{
POR \\ ELIZABETH HERNÁNDEZ GARCÍA \\ Universidad de Piura (Perú)
}

\begin{abstract}
RESUMEN
Pedro Gutiérrez de Cos no ha sido suficientemente trabajado en la historiografía peruana y es poco mencionado una vez que ha salido del Perú, razón por la cual no se ha conseguido profundizar en su opción por la independencia, postura que rigió su pensamiento y actuación hasta su muerte en Puerto Rico. Este artículo se propone entretejer tres aspectos en Gutiérrez de Cos: su trayectoria académica y profesional, desde sus inicios en los centros de enseñanza superior peruanos, hasta la consecución de los nombramientos más importantes en la esfera eclesiástica hispanoamericana; las ideas políticas conservadoras, pilares del gobierno monárquico y de su desempeño en sus respectivos destinos eclesiásticos; y, en medio de todo ello, la convulsión política independentista en el Perú, que consiguió reafirmar su monarquismo y le posibilitó otra mitra en ultramar.
\end{abstract}

PAlabras ClaVE: Partido de Piura, obispado de Huamanga, obispado de Puerto Rico, antiguo régimen, independencia del Perú y de América, patriotas y realistas.

\section{«A VERY STRONG COLUMN OF THE ALTAR AND THE THRONE»: PEDRO GUTIÉRREZ DE COS, BISHOP OF HUAMANGA AND PUERTO RICO (1750-1833)}

\author{
ABSTRACT \\ Pedro Gutiérrez de Cos has not been sufficiently studies in Peruvian \\ historiography and is scarcely mentioned once he left Perú, due to this it has not
}


been possible to conduct an in-depth study about his option for independence, position which prevailed among his thinking and acting until his death in Puerto Rico. This articles aims to lim three aspects in Gutiérrez de Cos: his academic and professional performance, from his beginnings in Peruvian higher education centers, until the obtention of the most important titles in the Hispanic-American ecclesiastic sphere; the political conservative ideas, pillars of the monarchic government and his performance in their respective ecclesiastic destinations; and, among all of these, the independentist political unrest in Perú. The monarchical spirit of Gutiérrez de Cos enabled him to acquire another bishopric beyond this ocean.

KEY WORDS: Party of Piura, Bishopric of Huamanga, Bishopric of Puerto Rico, old regime, independence of Perú and América, patriots and realists.

Recibido/Received 14-02-2008

Aceptado/Accepted 05-04-2008

La proclamación de la independencia en la ciudad de Lima en julio de 1821, motivó el retiro del Perú de varios miembros de la jerarquía eclesiástica virreinal en abierto rechazo al nuevo gobierno que se inauguraba, y convencidos de la pertinencia del sistema monárquico por el que se alejaban del país ${ }^{1}$. Pedro Gutiérrez de Cos, piurano y obispo de Huamanga cuando José de San Martín proclamó la independencia en Lima, fue uno de los que optó por mantenerse fiel a al anterior sistema, aun a costa de ganarse la animadversión del Protectorado en un ambiente de abierta desconfianza hacia quienes no juraban por la «patria» que se inauguraba.

No obstante su importancia en el alto clero hispanoamericano, sobre Gutiérrez de Cos existe un gran vacío historiográfico. Exceptuando algunos estudios, como los de Rubén Vargas Ugarte y Armando Nieto Vélez² , las investigaciones no han incidido en la complejidad de la figura de este prelado. La explicación radica en que Gutiérrez de Cos desaparece del escenario político peruano pocos meses después de la llegada de San Martín a Lima, interesando más a los historiadores, por razones obvias, los acontecimientos que se sucedieron en este espacio y los personajes que los vivieron ${ }^{3}$. Además, la historiografía polarizó du-

\footnotetext{
${ }^{1}$ Esta situación fue similar al resto de Hispanoamérica. Además de haber recibido una formación académica que rechazaba cualquier camino opuesto a la monarquía, Lynch opina que los obispos no podían mostrarse neutrales, de lo contrario eran llamados a capítulo. John LYNCH, «La Iglesia y la independencia hispanoamericana», en Pedro Borges (dir.), Historia de la Iglesia en Hispanoamérica y Filipinas, Tomo I, Madrid, Biblioteca de Autores Cristianos, 1992, p. 822.

2 Rubén VARgas UGARTE, El episcopado en los tiempos de la emancipación sudamericana, Tercera edición, Lima, Librería e Imprenta Gil, 1962. Armando NIETO VÉLEZ, «Notas sobre la actitud de los obispos frente a la independencia peruana (1820-1822)», en Boletín del Instituto Riva Agüero, 8, (1969-1971) 363-373.

${ }^{3}$ Esto se ratifica en la mayor cantidad de estudios sobre el obispo de Arequipa, José Sebastián de Goyeneche, que no emigró ni fue expulsado del Perú. Gobernó su diócesis hasta el año 1841. Se ha pu-

Hispania Sacra, LX

122, julio-diciembre 2008, 531-555, ISSN: 0018-215-X
} 
rante mucho tiempo la visión de esta parte de la historia peruana en dos facciones en conflicto: patriotas y realistas. Al formar parte de la segunda y estando fuera del Perú, fue más fácil relegarlo de las investigaciones subsiguientes. Por último, el «redescubrimiento» de Gutiérrez de Cos tiene que ver con el enfoque revisionista de la independencia de las provincias del Virreinato ${ }^{4}$.

En su persona confluyen aspectos fundamentales para el estudio de la etapa independentista peruana. Por un lado, es emblema de una elite letrada, heredera de una larga tradición virreinal, que no estuvo de acuerdo con los vientos renovadores que los libertadores representaban; en otras palabras, representa el conservadurismo del grupo de privilegio peruano frente a la revolución, sea por convicción monárquica o por intentar perpetuar el status quo. En segundo lugar, Gutiérrez de Cos simboliza la constante búsqueda de beneficios del clero peruano, posicionamientos importantes en un mundo socialmente escindido. Y, finalmente, su figura es importante en tanto que consiguió ser obispo de una de últimas colonias sujetas a la metrópoli española en América, cuando casi todo el continente se regía por sistemas republicanos. Además de otros factores, su adhesión a la causa real tuvo mucho que ver con la consecución de los más importantes beneficios eclesiásticos.

\section{EL ASCENSO EN LA ESFERA ECLESIÁTICA VIRREINAL}

Pedro Gutiérrez de Cos nació en la ciudad de Piura, al norte del Perú, el año $1750^{5}$. Procedía de un matrimonio peninsular-limeña: su padre, Tomás Gutiérrez de Cos y Terán, era natural de Barcenillas, en Santander ${ }^{6}$, y su madre, María Antonia de Saavedra y Seminario, de Lima ${ }^{7}$. Ambos contrajeron nupcias en Piura el año 1747. Pertenecía Gutiérrez de Cos a grupos sociales de mediana posición. Su familia no contaba con muchas posesiones de bienes raíces, indicador en el ámbito piurano de holgura u opulencia, sólo con la hacienda Chan-

blicado un último título sobre su figura: Ernesto RoJAs IngunZA, El Báculo y la Espada. El obispo Goyeneche y la Iglesia ante la «iniciación de la República», Perú 1825-1841, Lima, Fundación M. J. Bustamante de la Fuente, Instituto Riva Agüero, 2007.

${ }^{4}$ Gutiérrez de Cos despertó nuestro interés a raíz de la tesis doctoral, que se centró en la elite política, social y letrada de la ciudad de Piura en la época de la independencia. Fue el único piurano que consiguió ser obispo durante la época virreinal. Elizabeth HERNÁNDEZ GARCíA, La elite piurana ante la independencia del Perú. La lucha por la continuidad en la naciente República (1750-1824), Universidad de Piura, Instituto Riva Agüero (en prensa)

${ }^{5}$ La ciudad de Piura dista 1.000 k.m. al norte de la ciudad de Lima. En el año 1784 pasó a la categoría de partido, perteneciente a la intendencia de Trujillo.

${ }^{6}$ I. Ramos y G. Garrido-LeccA, San Miguel de Piura: vínculos de sangre 1650 a 1940, Piura, 1996, p. 96.

${ }^{7}$ Archivo Regional de Piura (en adelante, ARP), Serie: Notarial. Notario: Manuel Rebolledo. Leg. 12. Año 1833. Fol. 246. 
rro, obtenida en una modesta cantidad de pesos ${ }^{8}$. Tampoco existen referencias de participación de miembros de esta familia en la política local del entonces corregimiento de Piura. A pesar de ello, los Gutiérrez de Cos consiguieron costear la formación académica superior de los dos hijos varones, Francisco y Pedro, quienes llegaron a ser sacerdotes. De Francisco sólo se tiene noticia de que llegó a ser cura de la doctrina de Santo Tomás en la provincia de Chachapoyas, en la selva peruana ${ }^{9}$.

Pedro inició los estudios de filosofía y teología en el seminario de Trujillo donde fue primero pasante en Artes, ocupando luego la cátedra de Latinidad y llegando a ser vicerrector. Obtuvo el grado de Doctor en Cánones en la Universidad de San Marcos y fue abogado de la Audiencia de Lima. Se ordenó sacerdote en 1784 y sirvió en dos doctrinas del obispado de Lima hasta el año $1798^{10}$. De 1790 data su primer intento por obtener un beneficio de mayor jerarquía, pues solicitó una prebenda en el cabildo catedralicio limeño. Este año se presentó en tres ocasiones para una canonjía y dos raciones de la catedral del Cusco. Más adelante consiguió el nombramiento de capellán de coro de la catedral de Trujillo ${ }^{11}$. En 1794 figura como comisario del tribunal de la Inquisición y vicario juez eclesiástico de ese arzobispado ${ }^{12}$. En 1798 logró una media ración en la iglesia metropolitana de Lima, y, finalmente, en 1803 consiguió su objetivo inicial al ser elegido canónigo doctoral de esta catedral ${ }^{13}$.

Paulatinamente fue adquiriendo mayor protagonismo, hecho que se evidencia a finales de 1810, cuando el cabildo de Piura, su ciudad natal, lo eligió como uno de los candidatos para representarlo en las Cortes extraordinarias de Cádiz. Fue el segundo más votado, aunque la suerte favoreció a otro letrado piurano, José Antonio Sánchez Navarrete ${ }^{14}$.

Si bien no consiguió el importante encargo de diputado en las sesiones en Cádiz, la esfera eclesiástica le deparaba un posicionamiento mayor. El año 1814 obtuvo el puesto de chantre, y por último en 1817, tras el fallecimiento de José de Silva y Olave, fue nombrado obispo de Huamanga. Consagrado en la

\footnotetext{
${ }^{8}$ Esta hacienda les fue vendida por el presbítero Gregorio de Quevedo y Sojo, en la cantidad de 1.000 pesos alrededor del año 1745 . Al parecer no llegaron a adquirir muchos bienes más, pues para los años de 1810 esta hacienda era mencionada como única herencia de Marcelina, una de las hermanas de Pedro. ARP, Serie: Cabildo-Causas Civiles. Leg. 5. Exp. 92. Año 1758. Fol. 2.

${ }^{9}$ ARP, Serie: Notarial. Notario: Manuel Rebolledo. Leg. 12. Año 1833. Fol. 246.

10 AGI, Lima, 1583. Año 1794.

11 Ibidem, Fol. 3v.

12 AGI, Lima, 1583. Año 1794.

13 AGI, Lima, 1566. Año 1818.

${ }^{14}$ AGI, Lima, 741 N. 44. Año 1811. Fol. 30v. Elizabeth Hernández García, «La peregrinación de un realista en tiempos de crisis: el piurano José Antonio Sánchez Navarrete y su opción ante la independencia», en Pueblos, provincias y regiones en la Historia del Perú, Lima, Academia Nacional de la Historia, 2007, pp. 595-615.
}

Hispania Sacra, LX

122, julio-diciembre 2008, 531-555, ISSN: 0018-215-X 
catedral de Lima el 4 de agosto de 1819, tomó posesión de su obispado el 31 de ese mismo mes y año ${ }^{15}$.

Es la primera y única vez en la historia virreinal que tenemos a un piurano obispo en el Perú16. Pedro Gutiérrez de Cos había conseguido la meta más alta para un eclesiástico en su propia tierra ${ }^{17}$, pero los acontecimientos de la década de 1820 cambiaron momentáneamente dicha situación de preeminencia en este virreinato.

\section{UN VIAJE SIN RETORNO}

El contexto inmediato que rodeó el ejercicio de sus funciones fue la guerra por la independencia. Sus primeros escritos como obispo tuvieron como temática las providencias tomadas para evitar que circulasen papeles subversivos en su jurisdicción. Como ejemplo, la nota que elevó a la superioridad dando cuenta de que se habían tomado las medidas necesarias para acatar la real orden de 6 de noviembre de 1818, en que se instaba a los obispos a impedir la introducción de los periódicos Español Constitucional, y Gabinete de Curiosidades Políticas y Literarias de España e Indias ${ }^{18}$. Durante dos años, de 1818 a 1820, Pedro Gutiérrez manejó el obispado de Huamanga sin contrariedad de importancia, salvo algún que otro enfrentamiento entre su cabildo eclesiástico y una autoridad de la zona ${ }^{19}$, no obstante las noticias alarmantes del triunfo de los insurgentes de Buenos Aires cerca de las costas peruanas. Sin embargo, las tropas patriotas del comandante José Álvarez de

${ }^{15}$ AGI, Lima, 1577. Real Despacho dado en Madrid el 5 de octubre de 1817; Bulas pontificias de 16 de marzo de 1818.

${ }^{16}$ Durante el primer siglo republicano dos piuranos fueron obispos: José Domingo Arméstar, obispo de Trujillo (1875-1881), y José María de Arriaga, obispo de Mainas (1838-1852?). Ver: Rubén, VARGAS UGARTE, El episcopado en los tiempos de la emancipación sudamericana, Tercera edición, Lima, Librería e Imprenta Gil, 1962, p.

${ }^{17}$ De hecho, los estudios superiores no estaban directamente relacionados con los beneficios que aspiraban obtener todos aquellos que se formaban para sacerdotes; ello era mucho más palpable cuando, como en este caso, los letrados eclesiásticos procedían de provincias distantes de la capital virreinal. Los clérigos piuranos que formaron parte del alto clero virreinal constituyeron excepciones a la regla. Al respecto ver: Elizabeth HERNÁNDEZ GARCíA, «Clérigos de provincia en busca de una prebenda: la lucha de los vecinos piuranos por una canonjía en el Perú tardocolonial (1780-1821), en Valentina AYrolo (comp.), Estudios sobre clero iberoamericano, entre la independencia y el Estado-Nación, Salta (Argentina), Centro Promocional de las Investigaciones en Historia y Antropología (CEPIHA), Universidad de Salta, 2006, pp. 15-45.

${ }^{18}$ AGI, Lima, 650. Año 1820.

${ }^{19} \mathrm{El}$ ex intendente D. Manuel Quimper contra el cabildo eclesiástico de Huamanga sobre que no se le guardaban las prerrogativas correspondientes a su empleo. AGI, Lima, 650. Año 1820. Vargas Ugarte también afirma que, hasta 1820, no hubo en Lima, Trujillo, Mainas y Huamanga, trastornos políticos que distrajeran a los prelados del cuidado pastoral. Rubén VARGAS UGARTE, El episcopado en los tiempos de la emancipación sudamericana, Tercera edición, Lima, Librería e Imprenta Gil, 1962, p. 138. 
Arenales penetraron en la sierra central el año 1820, acelerando la escisión política. Gutiérrez fue testigo de excepción de todo este momento de tránsito.

A inicios de 1821 la situación política en el Perú era muy incierta. La expedición libertadora del sur se hallaba ya en el litoral peruano. Si bien José de San Martín mantenía una estrategia de conciliación, la flota comandada por Lord Cochrane $^{20}$ había empezado a hostigar algunos puertos importantes ${ }^{21}$.

Las sucesivas conversaciones de Miraflores y Punchauca no modificaron la situación. El gobierno español ordenó al virrey simplemente negociar, y la misión enviada desde la península complicó más esta paz inestable, mostrando ante la opinión pública la imagen de un gobierno virreinal débil y frágil.

En tanto se advertía que la corona española poco apoyo podía brindar a los intereses de las elites peruanas, fueron aumentando las adhesiones al bando patriota. Tropas y civiles se colocaron bajo el ala de la expedición sureña. En el ínterin, el norte virreinal proclamó su independencia, reconociendo la autoridad del marqués de Torre Tagle. Al no obtener ningún acuerdo satisfactorio en las conversaciones antes citadas, las tropas de San Martín penetraron en las provincias del interior del virreinato.

Gutiérrez de Cos no se hallaba en Huamanga cuando el ejército de Arenales se encaminaba a su diócesis. Estaba realizando la visita a su obispado. Cuando tuvo noticia de que Arenales había destacado un piquete de treinta hombres para prenderle y obligarle a reconocer y jurar la independencia, se dio a la fuga, dirigiéndose a Lima «por caminos extraviados entre nieves y desfiladeros». Cuando, poco después Arenales fue derrotado y desalojado de Huamanga, Gutiérrez de Cos intentó regresar al obispado, mas fue imposible porque los caminos estaban inundados de soldados enemigos, «conocidos con el nombre de montoneras», y de salteadores y asesinos.

Ante esta situación, permaneció refugiado tras las murallas de Lima ${ }^{22}$. Mientras, el obispado de Huamanga estaba acéfalo. La misma situación se repe-

\footnotetext{
20 Thomas Cochrane nació en Annsfield en 1775. Fue X conde de Dundonald; sirvió en la armada británica desde 1797. Participó activamente en la guerra contra Napoleón Bonaparte. Como representante del Westminster en el Parlamento, asumió actitudes que provocaron el rechazo de los más influyentes. Fue privado de su grado y honores, siendo desterrado a Boulogne Sur-Mer (Francia), desde donde fueron solicitados sus servicios por el gobierno de Chile (1817) para organizar una fuerza naval que contrarrestara la española en el Pacífico Sur. Llegó a Valparaíso en 1818, y desde 1819 se dedicó a hostigar los puertos peruanos y bloquear el del Callao. Alberto TAURO DEL PINO (ed.), Enciclopedia Ilustrada del Perú, Tomo 5, Lima, Peisa, 2001, pp. 698-699.

${ }^{21}$ Cochrane inició el bloqueo del puerto del Callao desde el año 1820. Poco tiempo antes, se dedicó a asolar otros puertos de la costa norte del virreinato peruano, entre ellos, Paita, Sechura, Supe, Huanchaco.

22 Oficio de Pedro Gutiérrez de Cos al Ministro de Estado, Gracia y Justicia. México, 8 de marzo de 1822. AGI, Indiferente, 1571. Fol. 1.
}

Hispania Sacra, LX

122, julio-diciembre 2008, 531-555, ISSN: 0018-215-X 
tía en Cusco. Los dos lugares tenían gran importancia en este contexto por ser el centro de la resistencia española hasta el final de la guerra. Los obispos se hallaban lejos de su feligresía en momentos en que el poder real se tambaleaba y más necesaria se hacía su prédica entre los fieles. El brigadier español Ricafort a solicitó el pronto retorno de ambos prelados ${ }^{23}$. El virrey Pezuela hizo lo propio:

[Al obispo de Lima y al de Huamanga]... he pasado oficios para que manden a los párrocos de sus respectivos distritos que se apersonen en sus propias feligresías añadiendo al dicho señor obispo [de Huamanga] se acerque cuanto sea posible a su diócesis, para que por sus persuasiones y ejemplo en unión con los señores curas, cimienten en sus feligreses la verdadera obligación e intereses, bajo cuyas reglas deban conducirse en las presentes circunstancias sus feligreses».24.

No obstante estos llamamientos, Gutiérrez permaneció en la capital a la espera de la evolución de los hechos. La situación no podía ser más desalentadora. A inicios de julio de 1821, el virrey La Serna dio a conocer su decisión de abandonar la capital para dirigirse a la sierra a recomponer el ejército y marchó el 6 de julio. La Serna huía así de una ciudad cercada en los caminos, bloqueada por mar, empobrecida y extenuada, de la que poco más se podía esperar para defender la causa real 25 .

A partir del 7 de julio, como es sabido, Lima fue un caos. En ese momento se produjeron las mayores adhesiones al bando patriota: «abandonados» por el virrey, los vecinos limeños vieron a San Martín como su salvador frente a la revolución social que se vivió en las calles de la capital durante aquellas cuarenta y ocho horas. Una junta de vecinos ilustres se dirigió al cuartel general del libertador a solicitarle su pronta entrada en Lima y la pacificación. San Martín aceptó y el 12 de julio, luego de haber restituido el orden, ingresó triunfalmente en la Ciudad de los Reyes ${ }^{26}$.

\footnotetext{
${ }^{23}$ Afirmaba Ricafort: «Nada influye más en los pueblos, que la doctrina de los párrocos; y ésta jamás tendrá todo su lugar no hallándose a la vista los señores obispos. Por ello gradúo de toda exigencia e importancia la incorporación en sus diócesis de los Señores Ilustrísimos del Cusco y Huamanga... Lima, enero 12 de 1821.» Félix Denigri LunA (ed.), Colección Documental de la Independencia del Perú, Vol. 3, Lima, Comisión Nacional del Sesquicentenario de la Independencia el Perú, 1971, p. 292.

${ }^{24}$ Ibidem, p. 298.

25 El 6 de julio de 1821, La Serna puso en ejecución una idea que manejaba desde hacía tiempo atrás, cuando era oficial del ejército español bajo el mando del virrey Pezuela. Mientras La Serna proponía una huida a la sierra para reorganizar las tropas y alejarse del «callejón sin salida» en que se había convertido Lima, Pezuela consideraba que desde Lima se podía vencer a los patriotas. Esta discrepancia en la táctica militar fue uno de los principales motivos del enfrentamiento entre ambos personajes, lo que, entre otras causas, motivó el «golpe» contra Pezuela, en enero de 1821.

26 Ver: Rubén Vargas Ugarte, Historia General del Perú, Volumen VI, Tercera edición, Lima, Milla Batres, 1981. Susy SÁnchEZ, «Clima, hambre y enfermedad en Lima durante la guerra independentista (1817-1826)», en Scarlett O’Phelan Godoy, La independencia del Perú. De los Borbones a
} 
¿Qué actitud adoptó Gutiérrez de Cos en estos momentos? Se encontraba igual de asustado que el resto de la vecindad limeña. Cuando el virrey salió de Lima, se enteró casi al mismo tiempo que se anunciaba el hecho, y también intentó huir, pero no lo pudo hacer «porque no habían mulas ni cabalgaduras a causa de haberlas tomado ambos ejércitos». Sin embargo, no se unió a las filas patriotas como otros miembros de la elite limeña.

La capital se tornó insegura para aquellos que no profesaban estar del lado de la «patria» o del protectorado inaugurado por San Martín. Aun así, asumió el riesgo que suponía no firmar el acta de independencia, ni participar de ninguno de los actos de la proclamación y jura de ésta ni del Estatuto Provisional: «Yo no asistí a estos actos, ni a ninguna función de celebridad; vivía retirado.» Sin embargo, el gobierno de San Martín procedió a asegurar la adhesión de las instituciones y máximas autoridades del ex virreinato, entre las que se encontraba el obispo de Huamanga.

Gutiérrez de Cos se enteró de que el libertador «se había resentido» por su decisión de permanecer al margen del nuevo gobierno. Ello motivó un primer intercambio de pareceres, en el que el obispo le reafirmó al propio San Martín su monarquismo, bajo el eufemismo de que correría la suerte de su diócesis, que en ese momento aún estaba bajo el dominio español. Sus palabras son elocuentes: «...le expuse [a San Martín] que mi diócesis de Guamanga permanecía sujeta a la dominación española y que yo no podía prescindir de la suerte de ella, que en el territorio en que me hallaba le obedecería en lo temporal, sin atentar contra su persona y providencias. Al parecer quedó convencido con mi exposición» 27 .

Gutiérrez estaba reconociendo que iba a respetar y acatar las disposiciones del nuevo gobierno en Lima, quizá por ello San Martín lo dejó en paz durante un tiempo; pero en el fondo, en su alegato el obispo mantenía su adhesión a los realistas, quienes tenían en Huamanga uno de sus principales centros de operaciones. Se podría inferir que Pedro Gutiérrez abrigaba la esperanza de que el orden nuevo fuera efímero. Pero tal y como se sucedieron los hechos en la capital, esta contraposición de lealtades se tornó inadmisible para el gobierno protectoral ${ }^{28}$.

Bolívar, Lima, PUCP, 2001, pp. 237-263. Timothy ANNA, La caída del gobierno español en el Perú: el dilema de la independencia, Lima, Instituto de Estudios Peruanos, 2003.

27 Oficio de Pedro Gutiérrez de Cos al Ministro de Estado, Gracia y Justicia. México, 8 de marzo de 1822. AGI, Indiferente, 1571. Fol. 1v.

${ }^{28}$ A poco más de un mes de haberse jurado la independencia en Lima, las fuerzas realistas de la sierra se hicieron presentes cerca de la capital a inicios de septiembre de 1821, entraron en el Callao, permaneciendo aquí dos días; se retiraron por falta de provisiones, llevándose consigo el tesoro del Real Felipe. La noticia de la cercanía del ejército realista generó un ambiente de desconfianza sin precedentes, agudizándose la persecución contra los anti-patriotas, y en especial contra los peninsulares. Ver: Rubén Vargas Ugarte, Historia General del Perú, Vol. VI, Lima, Milla Batres, 1981. Scarlett O'Phelan Godoy (comp.), La independencia del Perú. De los Borbones a Bolívar, Lima, PUCP, 2001. Paul Rizo-Patrón, Linaje, dote y poder. La nobleza de Lima de 1700 a 1850, Lima, PUCP, 2002.

Hispania Sacra, LX

122, julio-diciembre 2008, 531-555, ISSN: 0018-215-X 
La población en general se empezaba a mostrar descontenta con el nuevo sistema, perdiendo poco a poco popularidad la figura de José de San Martín. En esas circunstancias, era necesario convencer de la pertinencia del gobierno patriota, legitimarlo ${ }^{29}$, mucho más en las provincias aún sujetas al virrey.

Por ello San Martín insistió a Gutiérrez de Cos que jurase la independencia del Perú, «y que al mismo tiempo dirigiese a Guamanga una Pastoral para que allí se hiciese lo mismo... De manera que no pudiendo San Martín ocupar a Guamanga por la fuerza, intentaba revolucionarla por medio de mi Pastoral... neguéme con firmeza.» Esta vez San Martín no fue condescendiente y determinó que el obispo fuese expatriado. Por intermedio del ministro tucumano Bernardo de Monteagudo, el decreto de expulsión del Perú se le dio a conocer el 9 de noviembre de 1821.

Gutiérrez de Cos solicitó al gobierno le permitiesen disponer de un mes para poder retirarse del Perú; San Martín no aceptó, reafirmando que el plazo era de ocho días. A pesar de esta orden imperiosa, el obispo retrasó su salida hasta inicios de diciembre de 1821 porque, durante esas semanas, no encontró ningún navío que lo pudiese llevar a otro destino. El último oficio intimidatorio fue redactado el 3 de diciembre, en el que Monteagudo sentenció haberse excedido el plazo para salir del Perú, urgiéndole lo realizase a fin de evitar se tomase otra providencia ${ }^{30}$.

Se le dio pasaporte para la península. Gutiérrez se dirigió entonces al puerto del Callao; se presentó la fragata inglesa Harleston, procedente de Calcuta, con cuyo capitán consiguió negociar para que le dejase en Panamá. La persecución contra los anti-patriotas era grande. Temiendo que la «otra providencia» del libertador fuese la prisión en los castillos del Real Felipe mientras esperaba partiese la fragata, como se había hecho con el obispo de Trujillo, Carrión y Marfil, se embarcó en el navío el 4 de diciembre, dos días antes de que zarpase del Callao ${ }^{31}$.

Antes de partir, nombró al deán Tomás López de Ubillús, también piurano, como gobernador eclesiástico del obispado de Huamanga. López de Ubillús, posiblemente pariente lejano suyo ${ }^{32}$, era también monárquico. El propio virrey La Serna presentó a Tomás ante la metrópoli como uno de sus más importantes colaboradores en la preservación del Perú para la causa real ${ }^{33}$.

\footnotetext{
29 Sobre la legitimación del poder civil a través del poder eclesiástico, ver: Jeffrey KLAIBER, $L a$ Iglesia en el Perú: su historia social desde la independencia, Lima, PUCP, 1988. Pilar GARCíA JoRDÁN, «Poder eclesiástico frente a poder civil? Algunas reflexiones sobre la iglesia peruana ante la formación del estado moderno (1808-1860)», en Boletín Americanista, 34 (1984) 45-74.

30 Oficio de Pedro Gutiérrez de Cos al Ministro de Estado, Gracia y Justicia. México, 8 de marzo de 1822. AGI, Indiferente, 1571. Fol. 1.

31 Julio Elías (ed.), Colección Documental de la Independencia del Perú, Tomo VII, Vol. 2, Lima, Comisión Nacional del Sesquicentenario de la Independencia del Perú, 1971-1972, p. 391.

${ }^{32}$ En Piura los Gutiérrez de Cos se vincularon a los Ubillús en la segunda mitad del siglo XVIII, según consta en la documentación notarial.

${ }^{33}$ Oficio del virrey José de la Serna. AGI, Lima, 762, 1822. Fol. 1-1v.
} 
La fragata Harleston zarpó del Callao el 6 de diciembre de 1821 a las tres de la tarde ${ }^{34}$. El gobierno de Lima negó la licencia para el puerto de Panamá; el capitán tuvo que seguir de largo. Temiendo encontrarse con la escuadra de Cochrane, la embarcación llegó hasta el lejano puerto de Acapulco, donde el obispo inició una nueva etapa en su vida. Nunca más volvió al Perú.

Su salida fue aprovechada por el gobierno realista que se estableció a partir de julio de 1821 en el Cusco, bajo la dirección del virrey La Serna, para convencer a la población de las contradicciones de quienes supuestamente representaban «la libertad». El periódico cusqueño El Depositario, en fecha 1 de febrero de 1822, daba noticia de la salida del obispo de Huamanga:

Esta es la libertad decantada, esta es la independencia conducida por San Martín y sus secuaces del Perú... ¡Dios Eterno! ¡Cuándo se dará por satisfecha vuestra justicia, suspendiendo nuestras desgracias. La de mi anciano amigo está revestida de los caracteres de un asesinato, porque una expatriación tan violenta en edad tan avanzada, incluye o supone una muerte pronta ${ }^{35}$.

Al abandonar el Perú, Gutiérrez de Cos se convirtió en un emigrado. Pero a diferencia de cualquier otro que hubiese atravesado la misma coyuntura política, su condición de obispo le supuso un recibimiento y trato especial allí donde desembarcó: «....arribé al puerto de Acapulco, y encontré trastornado el Gobierno de México: me consterné pensando cuál sería mi suerte; pero fui recibido con demostraciones de cariño y de respeto a mi Dignidad, a que se agregan los auxilios que me ha ministrado y el hospedaje que me ha dado en su posada el M.R. Arzobispo de México que se halla en esta Villa de Cuernavaca ${ }^{36}$.

Según Bennet Stevenson, cuando Cochrane llegó a Acapulco el 25 de enero de 1822, en la fragata Isabel Española ${ }^{37}$, fue honrado con la visita de una comisión enviada por Agustín de Iturbide, presidente a la sazón de Méjico, «y por el obispo de Huamanga, que había sido desterrado del Perú por el Protector San Martín y nombrado por el Gobierno de México para la sede de Puebla de los Ángeles; de esta manera cambió su primer obispado, que le producía 12.000 dólares, por uno de $40.000 »^{38}$.

\footnotetext{
34 Julio ELÍAS (ed.), Colección Documental de la Independencia del Perú, Tomo VII, Vol. 2, Lima, Comisión Nacional del Sesquicentenario de la Independencia del Perú, 1971-1972, p. 391.

35 El Depositario, N. 59. Cuzco, 1-II-1822. Citado por Horario VILLANUEVA URTEAGA (comp.), Colección Documental de la Independencia del Perú, Tomo XXII, Vol. 3, Lima, Comisión Nacional del Sesquicentenario de la Independencia del Perú, 1973, p. 14.

36 Oficio de Pedro Gutiérrez de Cos al Ministro de Estado, Gracia y Justicia. México, 8 de marzo de 1822. AGI, Indiferente, 1571. Fol. 2.

${ }^{37}$ Ibidem, Fol. $3 \mathrm{v}$.

38 Estuardo NúÑEZ (comp.), Colección Documental de la Independencia del Perú, Tomo XXVII, Vol. 3, Lima, Comisión Nacional del Sesquicentenario de la Independencia del Perú, 1971, p. 315. La cursiva es nuestra.

Hispania Sacra, LX

122, julio-diciembre 2008, 531-555, ISSN: 0018-215-X
} 
De acuerdo a esta noticia, Pedro Gutiérrez de Cos aparecía al lado de Iturbide como una autoridad eclesiástica que brindaba su anuencia a quien se había proclamado emperador. Este apoyo, analizando las circunstancias, se entiende muy bien, a semejanza de la actitud que tuvo el clero mexicano ${ }^{39}$. La rebelión de Iturbide se explica por el temor a que el despotismo virreinal se reafirmase a consecuencia de la crisis y división política en la metrópoli en 1820, entre moderados y radicales, y ante la certeza de que las Cortes españolas no le otorgarían a América y a Nueva España auténtica autonomía. En su defecto, con el Plan de Iguala, Iturbide prometió la separación de España, una monarquía limitada y el respeto a todas las personas e instituciones tradicionales, entre las que se contaba el clero secular y regular, con sus fueros y propiedades ${ }^{40}$. En otras palabras, Iturbide se constituyó en el pilar del conservadurismo y del mantenimiento de los privilegios eclesiásticos; apoyarlo significaba apoyar a la Iglesia ${ }^{41}$ y mantener así el status quo. Cabe también destacar que la actitud del clero hacia Iturbide podía deberse al recelo que le inspiraba la insurgencia, y al deseo de alejar de ella a los americanos si la jerarquía eclesiástica tomaba la iniciativa ${ }^{42}$. Esa fue la situación que Gutiérrez de Cos encontró en México, y, por lo que se advierte, no le fue difícil adaptarse a ella.

No obstante las muestras de complacencia y respeto en México, Gutiérrez vivía económicamente limitado. Como su salida de Huamanga fue intempestiva y los caminos de Lima estaban cortados, nunca pudo recibir socorros de su obispado; en la capital vivió «de prestado», y cuando salió del Perú tuvo el apoyo económico de amistades que le proporcionaron pequeñas cantidades de dinero con las que se mantenía ${ }^{43}$. Al parecer, no gozaba de la pensión que desde el año 1811 la metrópoli había determinado asignar a los emigra-

39 Exceptuando al arzobispo Fonte, opuesto a la independencia de México y que tuvo luego que huir del país. Timothy AnNA, La caída del gobierno español en el Perú: el dilema de la independencia, Lima, IEP, 1981, p. 233.

40 Ibidem, pp. 223-225.

${ }^{41}$ La prohibición de las nuevas capellanías y las obras pías, el ataque a los conventos, órdenes monásticas y a las propiedades eclesiásticas, así como el decreto que abolía la inmunidad clerical de todos sin excepción, persuadieron a la Iglesia de que el verdadero peligro del liberalismo procedía de los constitucionalistas españoles, y no de los revolucionarios americanos. La jerarquía eclesiástica mexicana apoyó a Iturbide, y con ello contribuyó al éxito de su movimiento. John LYNCH, «La revolución como pecado: La iglesia y la independencia hispanoamericana», en John LYNCH, América Latina, entre colonia y nación, Barcelona, Editorial Crítica, 2001, p. 196.

${ }^{42} \mathrm{Al}$ respecto ver: Manuel Ferrer MúÑoz, La Constitución de Cádiz y su aplicación en la Nueva España (pugna entre antiguo y nuevo régimen en el virreinato, 1810-1821), México, UNAM, 1993, p. 87.

43 Además, el gobierno realista, cuando el obispo se quedó en Lima «viviendo bajo del gobierno de los disidentes», confiscó sus bienes y rentas, las cuales ascendían a la cantidad de 2.500 pesos. Biblioteca Nacional de Lima (BN), D786. Año 1824. Fol. 1. 
dos de las provincias americanas en rebeldía; a lo que se añadía el hecho de que formaba parte de un gobierno transitorio, temporal. Por ello se entiende su intención, desde el año 1822, de viajar a La Habana, «o a otro puerto de la dominación española» ${ }^{44}$.

Su incertidumbre era grande, además, porque para el año 1822 la guerra por la independencia en el Perú se hallaba en uno de sus momentos más delicados: la opción realista se tornaba nuevamente asequible y el gobierno protectoral estaba demostrando bastante ineficacia política ${ }^{45}$. Cabía, por tanto, la posibilidad de que las provincias del Perú volviesen al dominio español, con el consiguiente retorno de las autoridades civiles y eclesiásticas. De ahí que tampoco se decidiera a alejarse más del Perú, por si tuviese que volver a Huamanga.

Por ello afirmaba: «me hallo en la mayor confusión, porque si las Provincias de Trujillo y Lima ocupadas por el enemigo vuelven a la dominación española, como lo espero, me veré en la obligación de regresar al Obispado, y mientras más me aleje, me será más difícil y penoso el viaje...». Solicitó que la metrópoli le franquease el pasaje a la península con cargo de reintegro, para así encontrarse en lugar seguro desde el cual partir hacia Perú ${ }^{46}$, hecho que, como vemos, por las circunstancias, lo consideraba más que probable.

Pero Gutiérrez no viajó nunca a España. Parece ser que la caída de Iturbide y el triunfo de la primera república liberal en México aceleraron la salida del país de nuestro obispo, al que vemos residiendo en La Habana como emigrado en $1825^{47}$. En esta isla se desempeñó como gobernador eclesiástico ${ }^{48}$. Entre tanto, no dejó de solicitar un nombramiento de mayor reconocimiento.

44 Oficio de Pedro Gutiérrez de Cos al Ministro de Estado, Gracia y Justicia. México, 8 de marzo de 1822. AGI, Indiferente, 1571. Fol. 2.

${ }^{45}$ En 1822 el gobierno de San Martín se hallaba en su punto más alto de impopularidad. Las razones se centraban en la incoherencia entre su proyecto político y sus acciones (proyecto político monárquico incompatible con la persecución a los peninsulares y con la desaparición de la nobleza titulada); su ineficacia en la dirección de las acciones militares (p.ej. declinó atacar a los realistas en el Callao en 1821, se había perdido una importante batalla en el sur peruano, nombramientos a personas incompetentes); y su inclinación hacia el favoritismo por algunos militares argentinos vistos como «extranjeros». Desde inicios del año 1822, San Martín se vio en la necesidad de recurrir a la ayuda de Simón Bolívar.

${ }^{46}$ Oficio de Pedro Gutiérrez de Cos al Ministro de Estado, Gracia y Justicia. México, 8 de marzo de 1822. AGI, Indiferente, 1571. Fol. 2.

${ }^{47}$ El 9 de diciembre de 1824, en los campos de Ayacucho (jurisdicción de Huamanga), las tropas realistas fueron vencidas por los patriotas al mando de Antonio José de Sucre, lugarteniente de Simón Bolívar. Con la capitulación de Ayacucho ese día se consolidó la independencia del Perú. Suponemos que a partir de ese momento, Gutiérrez de Cos asumió que nunca más volvería a su diócesis, por ello se quedó en La Habana.

48 AHN, Ultramar, 2004. Año 1825.

Hispania Sacra, LX

122, julio-diciembre 2008, 531-555, ISSN: 0018-215-X 
Su situación finalmente movió el real ánimo. Luego de cuatro años de solicitudes y desconcierto, Fernando VII lo nombró obispo de Puerto Rico el 9 de junio de $1825^{49}$. Sucedió a Mariano Rodríguez de Olmedo, nombrado arzobispo de Santiago de Cuba. ${ }^{50}$ Pero, además de este nombramiento, la corona quiso premiar su lealtad durante la revolución de la independencia otorgándole una condecoración especial: un mes antes de desembarcar en Puerto Rico, el 9 de junio de 1826, se le concedió la Gran Cruz de la Real Orden Americana de Isabel la Católica ${ }^{51}$.

Mientras tanto, el gobierno peruano desde 1822 le había levantado el decreto de exilio. A un año de ser expatriado, el congreso constituyente puso todas las condiciones para su retorno. En esa fecha sólo había dos obispos en el Perú, José Sebastián Goyeneche en Arequipa y José Orihuela en Cusco. La Santa Sede no estaba en situación de reconocer la independencia del Perú, ni mucho menos de conceder al gobierno peruano las facultades propias del patronato regio como este pretendía. Se hacía imprescindible el retorno de algunos obispos para el gobierno pastoral del país. En la sesión del Congreso del 25 de septiembre de 1822, el diputado José Faustino Sánchez Carrión afirmaba que había que facilitar el retorno de Gutiérrez de Cos: «...que se halla en México y está pronto a jurar la independencia».

Consecuencia de esa solicitud, al mes siguiente la Junta Gubernativa determinó que Gutiérrez podía regresar al Perú, encargándose el gobierno de brindarle todos los auxilios que necesitase para tal efecto ${ }^{52}$.

La afirmación de «estar pronto a jurar la independencia», nos parece poco fiable. En primer lugar, no se ha encontrado ninguna prueba documental de esta intención en ninguno de sus escritos; en segundo lugar, parece lo más lógico que, de haber querido volver a su patria, habría aprovechado el decreto de la junta gubernativa; por último, y lo más contundente, su actuación hasta ese momento era el testimonio más evidente de su profunda e inalterable convicción realista.

Gutiérrez de Cos triunfó con la mitra en Puerto Rico. Pero, ¿acaso en algún momento intuyó que las circunstancias no le serían adversas al alejarse del

\footnotetext{
${ }^{49}$ Idem.

${ }^{50}$ Cabe destacar que en la consulta que el Consejo de Indias realizó para este obispado el 11 de mayo de 1824, Pedro Gutiérrez fue presentado en primer lugar, por delante de Gregorio Rodríguez, obispo de Cartagena, y también emigrado en La Habana. AHN, Ultramar, 2004. Exp 10. Años 18251826. También Gutiérrez de Cos había sido nominado en primer lugar en la terna para proveer el arzobispado de la isla de Cuba de la que fue elegido Rodríguez de Olmedo.

${ }^{51}$ AHN, Estado 7485. Año 1826. Al emigrado Hipólito Sánchez Rangel (obispo de Mainas y luego obispo de Lugo), también se le concedió esta condecoración en el mismo año. Por esta concesión Gutiérrez de Cos debía contribuir con 11.000 reales de vellón.

${ }^{52}$ Lima a 15 de octubre de 1822. Ibidem, p. 57.
} 
Perú? Durante sus largos años de permanencia en la ciudad de Lima, cultivó grandes amistades entre la elite capitalina. Uno de sus mejores amigos era Francisco Moreyra y Matute, al cual le unía también el vínculo del compadraz$\mathrm{go}^{53}$. La correspondencia era fluida entre 1819 y 1820 , cuando estuvo en Huamanga. Sin embargo, los años de guerras y su salida del Perú privaron a Gutiérrez del conocimiento de la suerte de sus conocidos. Fue en 1828 cuando volvió a tener noticia de Moreyra ${ }^{54}$. En respuesta a su comunicación, el ya obispo de Puerto Rico lo puso al día sucintamente de los caminos que había recorrido en sus años de expatriado. La correspondencia tiene un interés particular, pues nos muestra a un Gutiérrez de Cos completamente seguro de que el futuro no le sería tan incierto al optar por el monarca español; su decisión en esta línea, entonces, no fue improvisada:

Al tiempo de salir [del Perú] notaría alguno la serenidad de mi semblante: no era efecto de insensibilidad, ni de afectación, lo era de la previsión de lo futuro: mis cálculos no fallaron. En México recibí demostraciones claras de generosidad y respeto. En La Habana se me señaló una pensión de 3.000 pesos anuales; ejercí el oficio de Gobernador de ese Obispado, hasta que fui trasladado al de Puerto Rico con el distintivo de Gran Cruz, y donde estoy contento y robusto, gozando de quietud y sosiego, y voy a montar a caballo para visitar la isla...55.

Aunque Gutiérrez hubiera tenido tantas opciones para su carrera en Perú como en España, pues el Perú independiente necesitaba a sus prelados, sus cálculos giraron siempre en torno a su convicción realista, monárquica y regalista; en este sentido, él no quiso poner sus esperanzas en un gobierno republicano, y prefirió confiar en que aquel rey que le había llevado a la cabeza de la diócesis de Huamanga, le llevaría a un nuevo destino de similar relevancia. Además, su sentimiento de gratitud hacia aquella metrópoli que le había congratulado con la silla episcopal, fue, definitivamente, otro de los móviles que explican su vehemente defensa del orden tradicional, asuntos que se pusieron de manifiesto durante su gobierno eclesiástico en la diócesis puertorriqueña.

\section{En la isla de Puerto Rico: LA DEFEnSA DEl ANTiguo RÉGimen}

Cuando salió del Perú, Gutiérrez contaba con 71 años de edad. De emigrado se convirtió en obispo de una de las provincias de ultramar que aún se mante-

\footnotetext{
${ }^{53}$ Pedro Gutiérrez era padrino de bautizo de una de las hijas de Francisco Moreyra y Matute.

54 «Mi amado compadre y amigo. No quiero ponderar el gozo y alegría que inundó mi corazón al ver la carta de U. de 10 de junio último. Lo había contado a U. y encomendado a Dios entre los muertos de una pesadumbre...». AGN, Colección Moreyra y Matute. D1. 42-1255. Puerto Rico 28 de enero de 1829. Fol. 4.

${ }^{55}$ Ibidem, Fol. 4v. La cursiva es nuestra.
}

Hispania Sacra, LX

122, julio-diciembre 2008, 531-555, ISSN: 0018-215-X 
nían ligadas a la península. Su adhesión fue muy clara a favor de la corona, inclusive en momentos en que la opción patriota podía representar mayor seguridad y firmeza en el Perú. Esta misma actitud caracterizó su actividad pastoral en Puerto Rico. En este sentido, la corona pensó en él como un instrumento más para asegurar la adhesión de la isla a la monarquía. Su nombramiento, por tanto, no tuvo como móvil básico el sufrimiento de un súbdito fiel en el exilio, sino el acendrado realismo imprescindible en esas circunstancias en las que no cabía ninguna concesión ni intento contemporizador con ideas o personas que representasen «peligro» a la causa real.

Este apartado se centrará en las ideas políticas que Gutiérrez intentó plasmar en la diócesis de Puerto Rico, sobre todo a través de sus homilías, destacando la de 1826, y del Seminario Conciliar de la isla que consiguió inaugurar durante su gobierno. Ambas circunstancias revisten interés por el objetivo de esta investigación que busca el planteamiento ideológico respecto a la independencia americana, más que el análisis exhaustivo de su labor pastoral que, al parecer, tuvo el visto bueno de las autoridades y de la península.

El rey determinó su paso a su nuevo obispado en tanto le llegasen las bulas confirmatorias de su nombramiento ${ }^{56}$. El ejecutorial de la confirmación real se le dio el 23 de diciembre de 1825 . La aceptación y juramento de su nuevo cargo se hizo ante el capitán general de Cuba el 21 de abril de 1826. Luego se dirigió a su destino. Desembarcó en el puerto de la Aguadilla el 18 de julio de 1826, siguiendo su marcha a caballo hasta la capital ${ }^{57}$.

Nueve días después ingresó en San Juan de Puerto Rico en medio de una especial ceremonia de recibimiento ${ }^{58}$. El capitán general de la isla dio cuenta de la llegada del obispo con las mejores referencias. ${ }^{59} \mathrm{El}$ día de la toma de posesión del obispado, Gutiérrez predicó una homilía a sus feligreses, texto que no da pie a confusiones ni dudas sobre su postura. La homilía se iniciaba con las palabras del profeta Isaías: «Anda, pueblo mío, entra en tus aposentos, cierra

${ }^{56}$ La Bula confirmatoria de León XIII se redactó el 13 de marzo de 1826. AHN, Ultramar, 2004. Año 1825.

${ }^{57}$ AGI, Santo Domingo, 2523. Año 1826.

${ }^{58}$ El 27 de Julio entró en la Capital el Illmo. Sr. D. Pedro Gutiérrez de Cos en medio de un concurso extraordinario que lo acompañó a la Santa Iglesia catedral, a la casa de Gobierno y a su Palacio. Al desembarcar fue recibido en el muelle por las autoridades civiles, comunidades religiosas y por el clero con las ceremonias prevenidas para estos casos, y por todas las personas visibles. La música del regimiento de Granada acompañó el obsequio. En el Palacio se sirvió un lucido refresco, y mientras tanto, ejecutaba una orquesta varias oberturas y sinfonías escogidas. «Memorias geográficas, históricas, económicas y estadísticas de la isla de Puerto Rico, por D. Pedro Tomás de Córdova, Secretario de Córdova, Secretario Honorario de S.M. y del gobierno de la misma.», Tomo V. Año 1833.

59 «Este prelado, cuyas virtudes están pintadas en su rostro y de una acrisolada lealtad hacia el Rey N.S., me promete los más felices resultados en beneficio de esta isla...» AHN, Ultramar, 2004. Año 1825 . 
tus puertas tras ti, y escóndete un poco por un momento, hasta que pase la indignación.» Es evidente el simbolismo que le dio a estos versículos del Antiguo Testamento en relación con la revolución de independencia americana:

¿Qué prevención más ajustada a las circunstancias de la isla de Puerto Rico podrá hacer el Obispo a sus diocesanos, que la que hizo el profeta Isaías a los israelitas para que no se dejaran sorprender de los asirios? Que cierren las puertas y no den entrada en sus casas a los impíos que hablan de nuestra Santa Religión y de la moral de Jesucristo, para inducir a la incredulidad y pervertir las costumbres, ni a los conspiradores que tratan materias de Estado para provocar a la rebelión y a la independencia de la potestad de nuestro legítimo soberano el Rey de las Españas ${ }^{60}$.

La intención de la homilía era reflexionar acerca de los artificios de los que se valían los «enemigos de la religión y del sistema monárquico», que hablaban de luces, ilustración, y de la leyenda negra de España en su historia de la conquista; sin embargo, la alternativa que ofrecían era el desorden ${ }^{61}$. En su caso, esta afirmación no era concluyente sólo en tanto monárquico convencido, sino además, en tanto haber sido víctima de este desorden y caos vivido en el Perú, del desconcierto y expropiación de bienes, asuntos que se vivieron en toda Hispanoamérica en rebeldía, detalles de los cuales estaría muy bien informado.

La única manera de contrarrestar a los «enemigos» de la causa real era permanecer al lado de Fernando VII: «tributadle como a Rey la obediencia que se le debe de justicia, y como a padre de sus súbditos el amor y agradecimiento que exigen sus cuidados y desvelos sobre la tranquilidad y beneficio de sus pueblos $^{62}$. Su opinión acerca de la independencia de América es inequívoca y muy radical: «El consejo del Profeta nos parece el antídoto más eficaz para preservarlos del aire pestilencial de independencia que corre sobre las provincias que por desgracia se han separado de la obediencia de los Reyes de la España...»63.

Estamos ante una mentalidad típica del antiguo régimen. Hasta el final de sus días en el obispado, Gutiérrez de Cos mantuvo esta posición, reafirmando su adhesión a la corona en reiteradas ocasiones. En sucesivos informes se advierte que su principal preocupación es que la corona estuviese tranquila respecto a la sumisión de la feligresía puertorriqueña a la metrópoli, como si ésa hubiese sido la principal instrucción recibida junto con la prebenda. Así, por

\footnotetext{
${ }^{60}$ AGI, Santo Domingo, 2523. Año 1826. Fol. 1. La cursiva es nuestra.

61 «Tan necesario es estar prevenidos contra los enemigos de la Religión, como contra los del Estado: estos proceden con igual disimulo y artificio: ya excitan los ánimos a la compasión, ya al resentimiento, ya a la esperanza de mejor fortuna, sin descubrir sus proyectos hasta que hayan preparado a los que los escuchan a seguir sus máximas revolucionarias.»Ibidem, Fol. 2v.

${ }^{62}$ Ibidem, Fol. 3. La mayúscula corresponde al documento.

63 Ibidem, Fol. 4v. La cursiva es nuestra.
}

Hispania Sacra, LX

122, julio-diciembre 2008, 531-555, ISSN: 0018-215-X 
ejemplo, con ocasión del matrimonio de Fernando VII con María Cristina de Borbón, en febrero de 1830, el obispo dio noticia de haberse ordenado celebraciones y Te Deum en todas las iglesias del obispado de Puerto Rico, afirmando que la asistencia de las corporaciones institucionales así como el pueblo en general, sus aclamaciones públicas de regocijo, sus vivas y aclamaciones al Rey y a la reina, «...descubren su fidelidad, respeto y amor a la augusta persona de V.M. Dígnese V.M. de admitir estos sentimientos de lealtad, que yo procuro radicar en el corazón de estos humildes vasallos de V.M...» ${ }^{64}$ No cabe duda que también en estas expresiones existía un afán nada desinteresado del obispo de presentar sus propios méritos.

En la correspondencia del año 1831, Gutiérrez de Cos comunicaba al rey algunos datos interesantes de la isla, tras haberla recorrido; de la mano, venían nuevas alusiones políticas. La isla en su totalidad, afirmaba, «goza de paz y tranquilidad. Los pueblos están firmes en la fidelidad y amor a Nuestro Augusto Soberano... Quedo al cuidado de embarazar que se propaguen [las noticias falsas], y de cerrar la entrada a la seducción y al engaño» 65 .

Hubo muchas más circunstancias en las que puso de manifiesto sus convicciones favorables a la metrópoli ${ }^{66}$, de entre las que conviene destacar la visita pastoral a la isla en 1829, y la inauguración del Seminario Conciliar de Puerto Rico en 1832; acciones que, si bien pudieran tener en principio objetivos distintos, en el fondo el interés político las convertía en una sola preocupación.

Hacía muchos años que no se realizaba la prevista visita pastoral, por lo que la de 1829 constituyó un hecho relevante para la diócesis. Tuvo como objetivo central fiscalizar la actuación del clero regular y secular en el desempeño de sus funciones (licencias para confesar, predicar y celebrar), estado material de los templos y la corrección de las costumbres. Un segundo objetivo se centró en evitar la proliferación de ideas subversivas ${ }^{67}$. Finalmente, como era tradición en estas visitas, administró el sacramento de la confirmación ${ }^{68}$. Se inició en la catedral el 8 de febrero de 1829 y se prolongó 14 meses, hasta el 5 de mayo de 1830.

El informe indica que Gutiérrez estuvo en 55 pueblos y confirmó a 153.158 habitantes, «incluso los negros africanos y los criollos que hay en las haciendas

${ }^{64}$ AGI, Santo Domingo, 2523. Año 1830. Fol. 1.

65 Idem.

66 «Memorias geográficas, históricas, económicas y estadísticas de la isla de Puerto Rico, por D. Pedro Tomás de Córdova, Secretario de Córdova, Secretario Honorario de S.M. y del gobierno de la misma.», Tomo V. Año 1833.

67 «... a cuyo propósito os exhortamos a que exhibáis ante Nos los libros que contengan máximas antirreligiosas, subversivas de la moral cristiana o del buen orden y quietud del estado.»

68 «Y con este motivo encargamos a nuestros amados curas que instruyan antes de nuestra llegada a los padres de familia, y a los dueños de esclavos en la estrecha obligación que se hallan de presentar para la Confirmación a sus hijos y esclavos...» AHN, Ultramar, 2029, Exp. 2, No 4. Año 1830. Fol. 2v. 
de los respectivos distritos» ${ }^{69}$. En algunos pueblos bautizó gran cantidad de negros esclavos.

Estas acciones pastorales pueden tener otra lectura: una manifestación más del conservadurismo del prelado. En 1831 el Dr. Andrés López Medrano afirmaba en la Gaceta del Gobierno de Puerto Rico, que al confirmar a los negros, el obispo había colaborado con el poder político y militar de la isla para que fuesen «mejores esclavos, y con esto, más útiles a sus amos, más convenientes al Estado». Según López, era urgente confirmar a los negros esclavos para que así pudiesen resistir los ataques de la irreligión y las seducciones del libertinaje; en otras palabras, la esclavitud en sí no parece preocupar mucho al obispo ${ }^{70}$.

Fue éste un problema sobre el cual, al parecer, Gutiérrez no se manifestó. La relación entre los dueños de los esclavos y el poder político era aún muy fuerte, así como la mentalidad estamental de la sociedad americana, mucho más en este tema en el que tantos intereses confluían ${ }^{71}$.

El estado moral de la Iglesia en Puerto Rico era decadente, los sacerdotes incumplían las funciones elementales y las denuncias eran silenciadas por la propia jerarquía eclesiástica. A Pedro Gutiérrez le apremió que se dirigiese a su diócesis lo antes posible el capitán general de la isla, Miguel de La Torre. Este, en sus visitas había percibido el deterioro moral y disciplinar. Desde hacía algún tiempo había pedido medidas enérgicas y la llegada de un nuevo obispo ${ }^{72}$. En cuanto conoció a Gutiérrez de Cos, La Torre escribía esperanzado: «...no dudo remediará abusos envejecidos, vicios que deben corregirse y las costumbres de los ministros del altar que es indispensable reforme en muchos.... ${ }^{73}$.

El prelado indagó acerca de la conducta del clero a través de los vecinos de las provincias y sancionó con rigor cuando los casos eran de gravedad moral74.

\footnotetext{
${ }^{69}$ AHN, Ultramar, 2029, Exp. 2, No 2, Fol. 1.

70 Jesús NaVARro García, Control social y actitudes políticas en Puerto Rico (1823-1837), Sevilla, Excma. Diputación Provincial de Sevilla, 1991, p. 55.

${ }^{71}$ En el Perú, José de San Martín dio inicio a una política liberalizadora de los negros esclavos. El año 1823, el presidente José de la Riva Agüero dio marcha atrás en el decreto que liberaba a los esclavos que se enrolasen en el ejército; Simón Bolívar no modificó esta situación. En 1839 Agustín Gamarra determinó que los esclavos que habían sido liberados por San Martín, quedarían bajo el patronazgo de sus amos hasta la edad de 50 años. Finalmente, por estrategia militar, el año 1854 Ramón Castilla decretó la libertad absoluta de todos los esclavos, pero pagó por ellos a sus amos para hacer efectivo este decreto. Ver: Heraclio Bonilla, Guano y burguesía en el Perú, Lima, IEP, 1974. C. ConTRERAS y M. Cueto, Historia del Perú contemporáneo: desde las luchas por la independencia hasta el presente, Lima, IEP, 2000.

72 Jesús Navarro García, Control social y actitudes políticas en Puerto Rico (1823-1837), Sevilla, Excma. Diputación Provincial de Sevilla, 1991, p. 60.

${ }^{73}$ AHN, Ultramar, 2004. Año 1825. La cursiva es nuestra.

${ }^{74}$ Como lo fue el único caso que encontró en el pueblo de Utuado, de un clérigo «que se malversaba con una mujer de familia principal». El obispo ordenó su salida de la ciudad, bajo pena de llevarlo preso a la capital. AHN, Ultramar 2029. Exp. 2, n 2. Año 1830, Fol. 26.
}

Hispania Sacra, LX

122, julio-diciembre 2008, 531-555, ISSN: 0018-215-X 
Pero, a pesar de las quejas y apreciaciones del capitán general de la isla, Gutiérrez concluyó: «contra los curas no ha habido demandas ni acusaciones formales», pues «la conducta del clero es regular... otros [clérigos] hay a quienes es preciso reprimir, y otros a quienes no faltan defectos que se corrigen con la lenidad que previene el Santo Concilio de Trento»75. El obispo encontró varias demandas anónimas contra algunos sacerdotes, pero expuso que, luego de varias consultas a los pobladores y vecinos del lugar, aquellas eran infundadas.

La imagen que Gutiérrez muestra es la de un clero puertorriqueño bastante al margen de esa relajación de costumbres que era realidad cotidiana en el resto de Hispanoamérica en esa centuria, por lo que sus afirmaciones en este punto parecen poco certeras. El asunto, tal como se presenta en su escrito, pareciera ser restarle importancia a esta situación en contraposición con otra -la cuestión políticasiempre considerada por él como algo más urgente. Le interesaba en esta visita reafirmar la imagen del monarca en el pensamiento de su clero y feligreses. No era para menos, pues la situación en América en el año 1829-30 era de una paulatina crisis en la consolidación de las repúblicas, con idearios que tenían mucho más que ver con los caudillos de turno que con las pregonadas ideas de unidad e igualdad de las supuestas nuevas sociedades. Aun así, estos estados seguían representando motivo de inquietud para la metrópoli. Por ello, en el informe el obispo concluyó tajantemente que el alto y bajo clero puertorriqueño se encontraban al margen de las ideas revolucionarias ${ }^{76}$. Sostenía que el fundamento de esta fidelidad a Fernando VII era el temor a la anarquía y al desorden que los arrastraría si se adhiriesen a las ideas «insurgentes», pues sabían que ellos serían las primeras víctimas en cualquier mudanza de gobierno ${ }^{77}$; suficientes ejemplos les había brindado Hispanoamérica en su corta vida independiente, con gobiernos efímeros e inestables, como para reafirmar sus convicciones monárquicas.

En opinión del prelado, el clero y la totalidad de los habitantes vivían apartados de «ideas nocivas»; describía a sus feligreses como modelo de sumisión a la monarquía, contentos con el sistema que les regía: «...aman y estiman la unión con la España europea... He procurado imponerme de su carácter y modo de pensar: están firmes en la obediencia y amor a V.M.; son desde luego ignorantes por falta de instrucción, pero no de talento. Son animosos pero pacíficos: se contentan con poco».

A pesar de ello, para el obispo los peligros estaban cerca, mayormente en los pueblos próximos al mar, pues aquí era mucho más fácil la propagación de ideas liberales por el roce con los extranjeros y el ingreso de sus lecturas. No

\footnotetext{
75 Ibidem, Fol. 31.

76 «Yo he puesto el mayor cuidado en indagar si había alguno desafecto al sistema monárquico, y no he encontrado ni uno solo: todos los eclesiásticos son afectos a V.M.» Ibidem, Fol. 32.

77 Idem.
} 
consigna ningún nombre o situación concreta que tuviese que ver con esta previsión. Terminó el informe con la reiteración mucho más vehemente de la fídelidad de toda la isla, conclusión demasiado radical para ser del todo exacta:

Acaso no faltará algún desnaturalizado que abrigue en su pecho ideas de revolución. Los monstruos nacen en todas partes, y las sierpes se ocultan en las cavernas. Mas estoy en el concepto de que el que se atreviera a levantar la cabeza, sería sofocado en el momento. Este concepto lo he formado porque he visitado los pueblos, he visto las chozas de los campos, he andado a caballo por caminos arriesgados, he atravesado ríos, y he sufrido lluvias y soles, y me hallo sano, y en aptitud de repetir iguales operaciones y de ejecutar cuantas V.M. se digne mandarme ${ }^{78}$.

La visita le granjeó el reconocimiento de la corona ${ }^{79}$. El Fiscal mencionaba que era de elogiar la laboriosidad, celo y exactitud con que la había realizado, dando noticia de varios asuntos de interés para la corte, siendo el más importante: «...enterarse de la seguridad y orden público, que según dice se halla en tal estado que no ha encontrado ni un solo individuo que sea desafecto al gobierno monárquico ${ }^{80}$.

La preocupación por preservar a Puerto Rico de las ideas libertarias se evidenció también en la esfera educativa, en concreto, en la apertura del Seminario Conciliar en la capital. Si bien es cierto, la construcción de este Seminario fue anterior al gobierno eclesiástico de Gutiérrez de Cos, a él correspondió su puesta en funcionamiento.

El deán Nicolás Alonso de Andrade quedó como gobernador de la diócesis de Puerto Rico al ser ascendido al arzobispado de Santiago de Cuba Mariano Rodríguez Olmedo, en octubre de 1824. El año 1825, Andrade afirmaba que la situación de la educación en la isla se agravaba cada vez más dado que los jóvenes no podían ser enviados a Cuba por lo costoso del viaje; obviamente tampoco a Caracas o Santo Domingo pues supondría «exponerlos a que adopten las perniciosas costumbres que son propias en tales países» ${ }^{81}$. La situación se complicaba pues los estudiantes, frente a estas imposibilidades, acudían a Estados Unidos ${ }^{82}$, siendo esto considerado

78 Ibidem, Fol. 24 y 31. La cursiva es nuestra.

${ }^{79}$ El 20 de diciembre de 1830, Fernando VII envió una felicitación al obispo por el celo, dedicación y cuidado con que había llevado la visita pastoral; por ello «... se ha dignado aplaudir el fervor y apostólica constancia con que V.E. en su edad octogenaria ha practicado su visita pastoral, no menos que el noble y lacónico estilo con que explica sus felices resultados, y las interesantes nociones que suministra acerca de la estadística de la isla; y queda enterado con satisfacción de cuanto dice V.E. relativamente al buen orden en que la misma se halla, del carácter pacífico y honrado de los habitantes, sus fieles sentimientos, y decidida adhesión a su Real Persona y derechos soberanos.» AHN, Ultramar, 2029. Exp. 2. No 7. Año 1830. Fol. 5v.

${ }^{80}$ AHN, Ultramar, 2029. Exp. 2. N ${ }^{\circ}$ 5. Año 1830. Fol. 4v.

81 AGI, Santo Domingo 2525. Año 1825. Fol. 1.

${ }^{82}$ La educación en Estados Unidos era algo constante desde finales del siglo XVIII, en virtud a una

Hispania Sacra, LX

122, julio-diciembre 2008, 531-555, ISSN: 0018-215-X 
doblemente peligroso para el régimen. A Nicolás Andrade se debe el intento de sacar adelante el seminario e incluso una universidad, propuestas que realizó insistentemente el año 1825. El Consejo de Indias no aprobó la creación del primero por falta de edificio adecuado, y tampoco la segunda por falta de fondos.

Gutiérrez de Cos asumió totalmente el proyecto del Seminario Conciliar iniciado por Andrade llevándolo a buen término, debido principalmente al prestigio con que contaba en la corte: llama la atención que sólo tres años después de que el Consejo de Indias rechazara la propuesta de Andrade, reciba la aprobación real (11.IX.1828) y con los mayores elogios para el prelado ${ }^{83}$. Con los fondos que colectó el obispo Arizmendi a principios de siglo, los que legó Miguel Xiorro y otros, Pedro Gutiérrez empezó a levantar el edificio del Seminario en $1827^{84}$, poniéndose mucha más premura en su término e inauguración por la escasez de sacerdotes que enseñaran las buenas costumbres y, sobre todo, que vigilaran las ideas que se difundían en la isla ${ }^{85}$. No en vano Fernando VII en 1823 , luego del trienio liberal, exhortó a las órdenes religiosas a que se hicieran cargo de la enseñanza primaria, con motivos fundamentalmente políticos ${ }^{86}$.

La apertura en 1832 fue un hecho de gran relevancia, pues la diócesis, fundada en 1508, nunca había dispuesto de seminario. El Colegio se tituló «San Ildefonso Arzobispo de Toledo», bajo cuyo patrocinio se puso. Se edificó con la intención de que en el futuro, con fondos suficientes con qué dotarlo, pudiese servir «para los ejercicios literarios de una real universidad» ${ }^{87}$.

real cédula de 1802 en la que el rey muestra su desaprobación por la emigración de los jóvenes de la nobleza de la isla a aquel país para ser educados por los sacerdotes de San Sulpicio; el rey ordena el retorno de estos alumnos al seno de sus familias en la isla. Jesús NAVARRO GARCÍA, Control social y actitudes políticas en Puerto Rico (1823-1837), Sevilla, Excma. Diputación Provincial de Sevilla, 1991, p. 123.

83 V. Murga y A. Huerga, Episcopologio de Puerto Rico, Tomo VI, Ponce, Pontificia Universidad Católica de Puerto Rico, 1994, pp. 57-58.

84 Alfonso López Yustos, Historia documental de la educación en Puerto Rico, 1503-1970, Segunda edición, Puerto Rico, Sandemann Inc., 1984, pp. 77-78.

${ }^{85}$ En toda la isla sólo existían 133 presbíteros mientras que la feligresía ascendía a 315.352 almas, a lo que se sumaba la edad de muchos de los clérigos. AHN, Ultramar 2029. Exp. 2, nº 2. Año 1830. Fol. 24.

86 Jesús Navarro García, Control social y actitudes políticas en Puerto Rico (1823-1837), Sevilla, Excma. Diputación Provincial de Sevilla, 1991, p. 110. Este requerimiento se entiende porque, para ese año, la educación secundaria en Puerto Rico se encontraba en precario estado: debido a las medidas desamortizadoras del gobierno del trienio, los conventos habían suspendido sus labores y la enseñanza se limitaba a las clases de la Sociedad Económica Amigos del País y otras que ofrecían maestros particulares en sus hogares. Alfonso López Yustos, Historia documental de la educación en Puerto Rico, 1503-1970, Segunda edición, Puerto Rico, Sandemann Inc., 1984, p. 77-78.

87 «Estatuto Provisional para el establecimiento y gobierno del nuevo Colegio Seminario Conciliar de la Ciudad de San Juan Bautista, capital de la isla de Puerto Rico.» AHN, Ultramar 2029. Exp. 2, n 2. Año 1830. Fol. 1. 
Para tal «Seminario Conciliar» Gutiérrez redactó un Estatuto Provisional en el que se evidencia la formación eclesiástica tradicional característica de los centros de enseñanza virreinales en los que él se formó en el Perú. Con cierto matiz más igualitario que el usual en los estatutos de los seminarios erigidos en los siglos anteriores, mantuvo la estratificación socio-económica de la sociedad al restringir el acceso al seminario a jóvenes «de buena índole, naturales de la isla, de origen español, limpios de mala raza, hijos de legítimo matrimonio, que sepan la doctrina cristiana y leer y escribir correctamente.»

El análisis de las propuestas educativas escapa al objeto de este estudio. Pero cabe concluir que, en los requisitos sociales para el ingreso al seminario, así como en la relación de cátedras con que se inauguraron las clases, semejantes a las de cualquier institución educativa colonial, se reitera la imagen de un Gutiérrez de Cos defensor de las instituciones seculares, que luchó contracorriente en toda América por afirmar en su diócesis la misma mentalidad monárquica y regalista que caracterizó su vida, y que tantas satisfacciones personales le había brindado, no obstante el caos independentista ${ }^{88}$.

Gutiérrez de Cos estaba convencido de que la enseñanza de la elite puertorriqueña preservaría a la isla de las ideas de revolución, y hacia ello se abocó. Pero, no tuvo mucho tiempo de corroborar o no sus intuiciones.

\section{EL FINAL DE SU VIDA}

$\mathrm{Su}$ labor pastoral en la isla duró pocos años. Podría afirmarse que la apertura del Seminario Conciliar en San Juan de Puerto Rico fue la última de sus acciones importantes. El 7 de abril de 1833 enfermó gravemente. Sabiendo que su salud no se restablecería, nombró gobernador eclesiástico al deán de la catedral, Nicolás Alonso de Andrade y San Juan ${ }^{89}$. Pedro Gutiérrez de Cos falleció dos días después, el 9 de abril de 1833, a los 82 años.

Dado que durante su gobierno estuvo dedicado íntegramente a las labores espirituales y de instrucción en la isla en concierto con el cabildo catedralicio y el capitán general, ni antes ni después de su muerte hubo opiniones contrarias a su persona ni a su actuación. Al contrario, tres años después, con ocasión de un enfrentamiento entre el mismo capitán general y el vicario capitular eclesiástico por razón de querer este último realizar otra visita pastoral a la isla, se trajo a colación la benigna figura de Gutiérrez de Cos para justificar la demanda inter-

${ }^{88}$ Quedaba Cuba como otro baluarte de la tradición.

${ }^{89}$ AHN, Ultramar, 2005. Exp. 24. Año 1833. Fol. 1.

Hispania Sacra, LX

122, julio-diciembre 2008, 531-555, ISSN: 0018-215-X 
puesta por el capitán general de Puerto Rico ${ }^{90}$ Éste dio noticia a la corona de la muerte de Gutiérrez de Cos con muy sentidas expresiones ${ }^{91}$.

Fue evidente para el capitán general que Gutiérrez de Cos había sido un apoyo fundamental de la monarquía en la isla, pues lo definió como «una columna fortísima del altar y del trono». Su monarquismo, siempre fuera de duda, le hizo utilizar los medios litúrgicos para mantener la fidelidad de los pobladores. De alguna manera supo preservar la tranquilidad política, considerando la ubicación geográfica de la isla en el nuevo mapa político hispanoamericano. El capitán general, Miguel de la Torre, terminaba su comunicación diciendo: «En tal conflicto, sólo nos resta rogar al Todopoderoso ilumine a S.M. para que la elección de sucesor recaiga en una persona tan digna y benemérita como la que ha desaparecido, pues de esto depende en mucho el sosiego, la paz y la prosperidad de esta isla» ${ }^{92}$.Pedro Gutiérrez fue sepultado al día siguiente, 10 de abril de 1833, en la iglesia catedral de San Juan de Puerto Rico, con asistencia de todas las autoridades políticas y eclesiásticas de la isla, órdenes religiosas, cofradías, pueblo en general ${ }^{93}$. El cabildo eclesiástico sede vacante de Puerto Rico eligió provisor y vicario capitular al gobernador eclesiástico Nicolás Alonso de Andrade. El 19 de julio de 1833, la Cámara de Indias nombró al sucesor: Pedro Antonio Fernández de Córdoba ${ }^{94}$.

\footnotetext{
${ }^{90} \mathrm{El}$ enfrentamiento de opinión vino por el intento de una nueva visita pastoral, con el consiguiente malestar de los pobladores por los gastos que tendrían que hacer para preparar el recibimiento y manutención del obispo en cada pueblo. Miguel de La Torre, capitán general de Puerto Rico recuerda que Gutiérrez de Cos ha realizado una visita hacía poco tiempo y que, no obstante, no se tuvieron quejas de ningún tipo. AHN, Ultramar, 2029. Exp. 2. º 9. Año 1835-1836. Fol. 6v.

91 «Es con el mayor sentimiento que cumplo con el deber de participar a V.E. que ayer a las 9:15 de la mañana, tuvimos todos en esta capital la amargura de ver separar de entre nosotros al benemérito y justificado Dr. D. Pedro Gutiérrez de Cos, dignísimo obispo de esta isla. La irreparable pérdida de este virtuoso prelado ha causado una extraordinaria y general pena en estos habitantes, y la causará en toda la provincia luego que se difunda una noticia tan infausta.» AHN, Ultramar, 2005. Exp. 27. $\mathrm{N}^{\circ} 2$. Año 1833. Fol. 2v.

92 Ibidem, Fol. 3.

93 «En esta muy noble y muy leal ciudad de San Juan de Puerto Rico, a los 10 días del mes de abril de 1833 años, fue sepultado en esta Santa Iglesia Catedral, con asistencia del Ilustrísimo y muy venerable Sr. Deán y cabildo de dicha Santa Iglesia Catedral, ambos cleros secular y regular, seminaristas del Colegio de San Ildefonso, las Terceras Órdenes de Santo Domingo y San Francisco, y cofradías de esta capital, Sr. Presidente Gobernador y Capitán General de esta plaza e isla, Real audiencia, Excmo. Ayuntamiento, y demás cuerpos políticos y militares, y gran concurso popular, el cadáver del Excmo.e Ilustrísimo Sr. Dr. D. Pedro Gutiérrez de Cos, Caballero Gran Cruz de la Real Orden Americana de Isabel la Católica, Meritísimo Obispo que fue de esta diócesis...» AGI, Santo Domingo, 2524. N 1. Año 1833. Fol. 1.

${ }_{94}^{4}$ AHN, Ultramar 1068. Exp. 35. Año 1833-1834. Fol. 1.
} 


\section{APRECIACIÓN FINAL}

La vida de Pedro Gutiérrez de Cos resume parte importante del movimiento independentista americano, desde la perspectiva de un partidario del absolutismo, de alguien que siempre estuvo del lado de los «realistas». Este presbítero piurano, letrado, culto, vivió el momento de tránsito hacia un nuevo sistema de gobierno como la máxima autoridad eclesiástica de una diócesis peruana. Fue víctima de ese nuevo sistema al ser expulsado de su país de origen en el gobierno del Supremo Protector; vivió emigrado unos pocos años, durante los cuales, desde lejos, contemplaba la realidad de un Perú, su patria, perdida en el caos y el desorden. Esto marcó una huella profunda en sus ideas y actuación políticas, de tal manera que cuando llegó al obispado de Puerto Rico, podría decirse que había afianzado su marcado absolutismo y su rechazo a la revolución independentista. Su labor pastoral se centró en evitar que los vientos liberales llegasen a la isla, como puede verse en las acciones reseñadas. Murió fiel a este ideario político conservador, sobre el que giró la vida de las elites en el Perú.

Gutiérrez de Cos es un claro ejemplo de aquella privilegiada sociedad piurana y peruana que, hasta el último momento, hizo cuanto pudo por mantener su adhesión a una corona de la que tanto dependía. Desde la perspectiva de los beneficios, la peruana era una elite de nombramientos; su preeminencia dependía de la corona. Así, la tardía proclamación de su independencia también se puede enfocar desde este ángulo. A Gutiérrez de Cos la metrópoli le había concedido formar parte del alto clero peruano; era probable, como lo comprobó, que ese mismo gobierno le mantuviera en ese sitial. Los obispos, elegidos por la corona, quedaban subordinados a ella, y mucho más, los nombrados después del año 181495 .

Pero, además, en Gutiérrez hay que considerar un punto complementario a la adquisición de prebendas: la formación intelectual recibida en los centros superiores de enseñanza virreinales fomentaba esa profunda convicción monárquica. Más que en los que se instruían para el ejercicio de la jurisprudencia, la corona ponía especial énfasis en la formación conservadora de los bachilleres, licenciados y doctores en Sagrados Cánones, y mucho más, en la ilustración de los sacerdotes. La metrópoli y la Santa Sede aseguraban el pensamiento político conservador que debían transmitir los abogados en causas eclesiásticas ${ }^{96}$.

\footnotetext{
${ }^{95}$ A partir del año 1814, Fernando VII se aseguró de colocar en los obispados americanos a personas cuya fidelidad a la corona era absoluta. Cuando llegó el momento de la decisión, fue comprensible que ellos siguieran apostando por la metrópoli. John LYNCH, «La Iglesia y la independencia hispanoamericana», en Leslie BetHell (ed.), Historia de América Latina, Vol. 5, Barcelona, Editorial Crítica, 1991, p. 204.

${ }^{96}$ El bachiller en Cánones, por ejemplo, juraba «ni oír, ni enseñar ni aún con título de probabilidad las [doctrinas] del regicidio y tiranicidio contra las legítimas potestades...»AGI, Indiferente General,

Hispania Sacra, LX

122, julio-diciembre 2008, 531-555, ISSN: 0018-215-X
} 
La formación eclesiástica consolidaba los principios jurídico-políticos adquiridos, de tal manera que, cuando la amenaza de la revolución se hizo presente, fue vista esta como un extravío. La mayoría de obispos en Hispanoamérica rechazó la independencia porque la identificó como herejía o rebeldía frente a una autoridad política consagrada por la divinidad. Así se entiende que en la homilía de 1826 y en el informe de 1829 , Gutiérrez de Cos sentenciase a los independentistas con muy crudas expresiones. Todo este conjunto de motivaciones estuvo presente en la opinión que este prelado sobre de la independencia, y en su lealtad al orden establecido durante siglos.

Pedro Gutiérrez de Cos fue una figura muy importante, pues ascendió a la cúspide del poder eclesiástico hispanoamericano en dos momentos clave, 1817 y 1825, años en los que la corona necesitaba súbditos fieles en los más importantes nombramientos. La metrópoli había acertado en su elección. En su caso, la independencia no afectó significativamente su trayectoria profesional, pues se mantuvo en el mismo sitial aunque en distinto espacio geográfico. No necesitó adaptarse al cambio en el Perú; éste fue percibido a leguas de distancia, factor importante, también, en su postura. Su vida es la mejor muestra de la complejidad del proceso de independencia de América. En él las fidelidades, motivaciones personales, aspiraciones burocráticas y circunstancias del momento se conjugaron con las ideas que secularmente habían marcado la conciencia colectiva de los americanos. En medio de las acciones bélicas, persecución y represión política, Gutiérrez de Cos apostó por el monarquismo. Como él mismo afirmó, sus «cálculos no fallaron».

1507. Año 1767. Fol. 4. Ver al respecto: José Luis Mora MéRIDA, «La formación política en la Universidad hispanoamericana: proyección urbana e ideología política «nacionalista» de las facultades eclesiásticas», en José Luis PeSeT (coord.), Ciencia, Vida y Espacio en Iberoamérica, Vol. II, Madrid, CSIC, 1989, pp. 557-577. 